\title{
The Transition of Urban Toponymy of Izmir: Impacts of Modernism and Nationalism on the Street Names
}

\author{
By Orcun Cobangil
}

\begin{abstract}
Street names are one of the most important indicators of urban identity and memory as they can manifest different parts of urban life. However, after the emergence of modernity and nationalism, street naming process has become a subject for political agendas to disseminate their influences over urban places by favoring some names over the others and this process has some inevitable impacts on urban memory. Therefore, this article aims to evaluate this process by examining the history of the street names and street naming in Izmir as it provides an appropriate case in this regard due to the transformations it went through. While analyzing it, the paper does not only focus on the basic categorization of the street names but also the political mentality behind them. In this context, it shows the relationship between the modernist and nationalist tendencies in the urban geopolitics and the transformation of the street names.
\end{abstract}

Keywords: toponymy, street naming, urban memory, urban identity, Izmir

\section{Introduction: Collective and Urban Memory}

The relationship between place and memory was discussed at length in the course of history especially since Cicero who invented a method to remember things by imagining them in some basic spaces such as houses, arcs and the like in the mind (Perlman 1988: 49-50). This approach underpins the role of basic spatial elements in the process of remembering by bounding the concepts of memory and place together. Centuries later the same approach can be followed in Halbwachs' renowned work "The Collective Memory" in which he argues that people are deeply attached to their nearest surroundings (houses, streets, neighborhoods, etc.) or their "material aspect". Residents find stability and comfort in their surroundings which basically remind them that life simply continues whatever a major detrimental breakdown occurs outside of their places. Depending on their nearest places people can access to some comfort and therefore, they tend to resist the interventions aimed at changing their places. According to Halbwachs (1992), the level of the resistance against policies aimed to change their place is closely related to the level of dependence of their collective memory on place. That is the main reason that people do not alter their built environment so easily such as demolishing and rebuilding. Social groups' attachment to their places impedes it (Halbwachs 1992: 3-5). Attachment of social groups in a defined place of their closest environment such as houses, streets and neighborhoods is also the main

* Research Assistant, Faculty of Economics and Administrative Sciences, Dokuz Eylul University, Turkey. 
reason explaining why collective memory depends on place; the features of this attached place simply contribute to the formation of collective memory. In this sense, urban places provide a unique environment for this formulation as their role is to be "the theater of our memories" even though cities are constantly being changed due to social realities. In the course of urban transformations, memories are being buried down in the physical environment (Boyer 1996: 31). But the relationship between urban place and memory cannot be explained simply by physical places, it is also about the social groups who handle all kinds of daily interactions in these places. The term "group" is particularly of importance here as collective memory is more than a total sum of individual memories; it also encompasses group trends and characteristics to which it belongs (Green 2011: 99). Therefore, it can be assumed that the spatial nature of collective memory has both material and social backgrounds. Some discuss that modern societies try to intervene this connection in order to create "a memorial background" in accordance with their "histories" combined with their political mentalities. The examples of this process can be traced especially in urban places. French scholar Pierre Nora evaluates this phenomenon by the concepts of "milieu de memoire" and "lieu de memoire".

According to Nora (1996), modern societies try to design a cure to cope with the seemingly inevitable incident of losing their memories so, they transform "milieu de memoire" to "lieu de memoire". This transformation also marks the dominance of history over memory as while milieu de memoire contains the vivid and continuing parts of collective memory based on its habitants' doings in their most mundane and daily lives, lieu de memoire is the manifest of designed and politically corrected place of memory. In order to create lieu de memoire, history captures memory by using some modern archiving methods. Hence, history creates a designed representation of the past in the form of lieu de memoire at the expense of losing living remnants of the past found in the form of milieu de memoire (Nora 1996). In other words, milieu de memoire is created in an organic way in the course of history of social groups and expresses the real features of collective social memory but, lieu de memoire is an artificial place excluding the real features of collective memory while including only a fixed "favorable" part of it. The dominance of lieu de memoire has become evident with the advent of modernism and nationalism which aim to shape the social formations and relations in accordance with their visions. These assumptions can shed light when it comes to define the urban memory and urban places of memory and trace the transformation of milieu de memoire to lieu de memoire in urban areas. In this context, street names are the perfect examples imbued with collective urban memory and the role of street naming process (i.e., how streets are named) can provide some observations about the interventions of political/ideological mentality on the (re)formulation of urban memory. The street naming process based on patterns of lieu de memoire defined by Nora, which is the dominant method in Europe, shapes the street names in accordance with the nationalist commemorative narratives of nation states. However, in addition to this method, a modernist perspective based on letters and numbers, dominant in the United States, also goes hand in hand as to it aims to spread its rationale in order to create 
an ordered city. This system might also have some impacts on urban memory and identity. Hence, this paper will try to discuss the role of street names and the process of street naming by evaluating their characteristics and their meanings for urban memory in the case of Izmir, Turkey. As a city having been changed completely in the beginning of the $20^{\text {th }}$ century, it will be worthwhile considering the role street names in urban memory of Izmir and modernist and nationalist impacts on them in the course of near history.

\section{Methodology}

In the context described above, this article will discuss the relevant literature and theories about street names/street naming at first. Then, it will evaluate the process of street naming and street names in Izmir based on the pre-Republican (Smyrna) and Republican (Izmir) periods of the city. The relationship between the urban memory of the city and the street names, which is the main research question of the paper, will be discussed by the experiences found in these periods.

Since the aim of this paper is to depict the impacts of modernism and nationalism on the street names in the case of Izmir, the street names found in two different time periods of the city will be presented with the relevant historical developments and sources of urban memory/identity. The insurance map of the city created by Goad in 1905 will be used to show the street names at the prenationalist stage (i.e., the Ottoman period). For the next (nationalist and modernist) period, the meeting minutes of the Municipality and local newspapers in 1937 (which is the year when all of the street names were changed), both of which are found in the archives of Izmir Metropolitan Municipality, will be used in order to demonstrate the complete changes of street names and the mentality behind new street naming. As the insurance map shows only the historical central part of the city, the same area has been selected for the contemporary period, therefore this paper only covers the street names found in the city center for the both periods.

For the categorization of street names of the both periods, the literature about street names presented above has been taken into consideration to some extent particularly in the creation of categories of street names of contemporary Izmir (such as numbers (alphanumerical system) and republican values (commemorative street names)). However, categories are generally constructed by the author based on the historical identity of the city, which will be discussed.

\section{Street Names and Street Naming}

In order to evaluate relationship between street names and urban memory, "a critical reading of toponmys for wider social context" (Yeoh 1996: 298) is needed. Rose-Redwood et al. (2017) trace the toponymic studies back to their foundations in their study. In the first three quarters of the $20^{\text {th }}$ century, toponymic studies were confined to the categorization of names with their cultural backgrounds. However, after the 1980s three main critical toponymic approaches have emerged: City-text 
approach which is based on the use of semiotics particularly in the process of commemoration and practices of renaming street names according to the political mentality; cultural arena approach which deals with the interaction between street names and socially marginalized groups in urban landscape and, performative space approach which is more deeply concerned with the use of street names in daily lives of their users and goes beyond the representative nature of names in its analysis (Rose-Redwood et al. 2017: 24-25). Bearing their differences between each other in mind, it should be stated that these three approaches cannot be separated completely as all of them consider power relations and political mentality behind the creation of street names to a certain degree and in order to achieve their goals they do a lot more than just a basic categorization of street naming process does. This paper will mainly rely on the assumptions of city-text approach as it is aimed to evaluate the semiotics about the official street (re)naming process with actual street names found on the maps from different time periods considering their commemorative functions and roles in shaping urban memory and lieux de memoire as discussed below particularly in Azaryahu's assumptions.

Street names can basically serve two main purposes: Firstly, they mark streets for spatial orientation so they function as a way of navigation method. Secondly, they are a manifestation of symbolic values and political order in their commemorative use as they link "national past" to urban geography. They attach meanings of urban landscapes to the past by shaping urban memory with these symbolic values (Neethling 2016: 145-147, Light 2004: 168, Azaryahu and Kook 2002: 210, Alderman 2003: 171-172). Azaryahu defines their roles in navigation as the primary function by definition that the main function of street names (odonyms) are to organize spaces in a settlement for the sake of orientation by referring to spaces with defined markers. Neethling argues that in this use, their initial meanings which were attributed to them by their first users become less important since people start using them to navigate and their names simply become markers. But this process needs to be evaluated deeply considering the second effect of street names which Azaryahu defines as commemorative function. In that use, street names are constantly being used to create historical memory of city dwellers (Azaryahu 1996: 312, Neethling, 2016: 145). The commemorative power of street names comes from the fact that streetscapes are the places where the formulation of social production of urban spaces within collective identity and memory takes place. (Rose-Redwood et al. 2017: 24). "Collective identity is constructed by and experienced through shared symbols and presentations" and it is defined and maintained in people's attachment to these symbols and representations (Azaryahu and Kook 2002: 198-199). These can be found embodied in street names therefore they can infiltrate into the mundane lives of city dwellers as people use streets in almost every aspect of their daily lives. The interaction between street names and daily life can be explained even by the frequency of their use in the spoken language as some discuss that "the way the name is pronounced reflects, and contributes to, the constitution of an imagined community" (Kearns and Berg 2002: 284). This process provides a perfect opportunity for political regimes and ideologies to spread their influences. 
Therefore (re)naming street names is a very powerful political instrument in the urban politics.

Before the $18^{\text {th }}$ century, street naming had not been an 'official' process; it had been created by local topography and history but, since then it has been managed by administrative authority. What this meant for street names is that the interferences of the administration on street names diminished the effects of locally lived history on street names in favor of the (nationalist) political agendas of the administration; administrative authority started deciding which names are suitable and appropriate to commemorate as a street name. In other words, this "official" process had detrimental effects on the continuity of locally formed urban memory while it has favored the nationalist ideals. But at the same time, new "historical" street names became an example of lieu de memoire as they introduce an authorized version of history while molding the symbolic values into the urban spaces (Azaryahu 1996: 312-313). In this context, street names are being chosen and renamed in par with desired nationalist political order because the new political order needs a new historical narrative to be imbued in the urban geography in order for nationalist mentality to manifest itself through its indicators on urban areas by symbolic values which constitute collective identity and memory (Light 2004: 155). This is not a linear procedure as there are many candidates to be commemorated in urban spaces so, street naming itself reflects contesting power relations in shaping urban memory (Azaryahu 2011: 28). When street names are defined, they also demonstrate a hierarchy of historical memory (Azaryahu and Kook 2002: 199) in which some forms of commemorations have won the struggle against the others over urban spaces. As indicated above, these authorized versions of history are being disseminated into mundane lives by the use of street names imbued with politically authorized commemorations.

Another way of naming streets, especially in the United States, is to use numbers and letters. This alphanumerical street naming system is mainly based on the primary function of street naming; to address and distinguish streets in order 'to regulate administrative control' over cities (Azaryahu 1996: 312). This is also an implementation of the Cartesian system on urban landscapes as these signs provide measurement in terms of locations of streets in relation to each other based on the logic of mathematical techniques (Rose-Redwood and Kadonaga 2016) therefore it basically makes rational Cartesian paradigm predominant in urban geopolitics for creating "ordered" cities. At first glance using alphanumerical street naming system seems politically neutral as numbers do not seem related to political values but, if these numbers replace the previous actual names by removing old street names consisting full of actual words, it can be assumed that alphanumeric names erase the traces of urban memory and fill them with the modernist Cartesian logic instead. This policy also constitutes another politically biased decision about urban spaces: it erases the non-desired past and replaces it with seemingly value free rational categorization in a modernist perspective. In other words, even though this system itself does not have the function of commemoration (i.e. lieu de memoire), it still has implications for the relationships between place and collective memory (i.e., milieu de memoire). While street numbers rationalize the urban spatial organization, they disseminate the modern 
state's geo-locational regime (Vuolteenaho 2012, Harris and Lewis 2012). As Rose-Redwood et al. (2017: 31) put it into words, both words and numbers are important elements in the formulation of approved narrative of urban memory.

\section{An Overview of Urban Identity and Memory of Smyrna/Izmir}

According to Mansel (2014: 221), there are eight basic characteristic features distinguishing the Levantine port cities from the others; "geography, diplomacy, polyglottism, hybridity, trade, pleasure, modernity, and vulnerability". Having been the largest external trade port city of Ottoman Empire (Tasci et al. 2015: 62), Izmir - or back then, Smyrna- was no exception in this regard: the foundations of the urban memory of Smyrna ${ }^{1}$ lay down on these elements which are interrelated between each other. Therefore, it is worthwhile considering how these elements formed the near history of the city and its urban memory.

The rise of Smyrna in the course of near-history started in the beginning of the $17^{\text {th }}$ century when its trade incomes surpassed the trade income of the rival port town of Chios. The European consuls started moving in Smyrna following the success of the city in its trade performance. The presence of these newcomer Europeans who were generally the English, the Venetian, the French, and, the Dutch became visible in the geopolitics of the city. An international community was being formed whilst the importance of the city in the international commerce between the Ottoman Empire and the West was increasing (Mansel 2011: 17-20). Smyrna could gain an important role in the trade networks against its rivals thanks to its strategic position between the East and the West and therefore it could attract many populations from the different parts of the world who were gathering in the city (Özveren 2010: 120). In other words, its geography -the city is located at the very end of a highly sheltered gulf of Izmir-helped the city became a trade center and the trade brought a plural society consisting of different communities and polyglottism. Smyrnelis (2009a: 17-22) also points outs these elements whilst defining the main patterns of urban history of Smyrna; a main trade port city and a connecting hub not just for trade goods but also for ideas and cultures, a host city presenting an earlier version of "Modernity" for a plural cosmopolitan society consisting of many non-Muslim populations in a Muslim Empire and a cultural and intellectual center in the Mediterranean.

The different neighborhoods for the different communities emerged in the $16^{\text {th }}$ and $17^{\text {th }}$ centuries (Mansel 2011: 24) and the urban settlement patterns in Smyrna were formed according to these different communities (Serçe 2010: 26). In their neighborhoods different languages (Turkish, Dutch, English, French, Italian, Provençal, Greek, Armenian, Ladino) were spoken and different religions (Islam, Roman Catholic, Protestant, Anglican, Greek Orthodox, Armenian Gregorian,

\footnotetext{
${ }^{1}$ From now on, the word "Smyrna" will be used when referring to the city in the Ottoman period. On the other hand, "Izmir" will be used to refer the post-Ottoman, contemporary city of the Republic. This duality is followed because of the fact that "two cities" differ in so many subjects one of which are street names. The name "Izmir" was made official name of the city in the Republic period. However, the name Izmir itself is derived from the name Smyrna.
} 
Judaism) had their own believers. Even though the city hosted a plural and cosmopolitan society, their neighborhoods were separated and this separation was a reflection of the relevant roles of different communities in the logic of trade system of the city (Bilsel 2009a: 145). The settlement patterns between the $16^{\text {th }}$ century and the beginning of the $20^{\text {th }}$ century therefore can be roughly summarized as follows: Whilst Europeans (Franks, Levantines) settled in the coastal part of the city that was very close the port, Muslims remained in the inner parts and the neighborhoods of local Non-Muslims (Greeks, Armenians and Jews) were located between the European and Muslim quarters reflecting local non-Muslims' commissioner role between Muslims and Europeans in the commerce system of the city.

This separation between different communities in the urban geography of the city led some researchers to assert that "even though these communities could manage to live together, the contact amongst them was limited and they were alienated to each other" (Kayin 2010: 360). This assumption also implies that the urban identity of Smyrna consisted of the identities of 'fragmented communities' and each neighborhood had different sets of memories regarding their attachments to their neighborhoods. However, while different communities perceived the city from their own perspectives, these perspectives were being formed in relation to each other. So, both the similarities and differences were seen in the ground of "common of interests" (Smyrnelis 2009a: 19-20). Hence, the identity of cosmopolitan Smyrna presented both singularity and plurality consisting of elements that were created interdependently.

The formulation of urban identity of Smyrna should be evaluated in a broader context that includes the impacts of some political and social movements happened throughout the Ottoman Empire on the Ottoman port cities where affluent NonMuslim communities were being flourished and culminating power (Köksal 2018: 53-54). Both nationalist and new Ottomanism movements had some profound impacts on these communities. Whilst nationalism strengthened the national identity of the communities at the expanse of the interests of the Empire, Ottomanism movement tried to overcome this issue by bringing forth the concept of the imperial citizenship encompassing all the subjects of the Empire regardless of their nationalities and religious beliefs. The tension between these movements were not feeble but the concept of new Ottoman citizenship helped Smyrna build new social spaces in a "modernist" way with the appointments of new Ottoman bureaucrats as the governors of the city who received a westernized education. Kurlı also asserts that both European colonialism and Ottoman Tanzimat Reforms had some considerable impacts on the modernization of the city in this regard (Kolluoğlu Kırlı 2007: 220). Ottoman high officers collaborated with European companies to construct new facilities in the city like the port and the promenade and tried to deal with the considerable poor situation of the Muslim quarter of the city.

The Cosmopolitan era of Smyrna, which had been survived under the tension mentioned above came to the end after the World War I. Smyrna, which was once an agent of cosmopolitanism, found itself at the front of nationalism (Mansel 2011: 207). After the Great Fire in 1922, even the physical materials and buildings 
which epitomized the cosmopolitan past of the city literally burned down to the ground and the city lost its remaining non-Muslim populations due to the population exchange between Greece and Turkey in 1923. A new city, Izmir, was born from the ashes in the plans of the new modernist urbanization process of Turkey. In fact, Smyrna was already constructed under the influence of modernism in the late Ottoman period but this new version of modernism in the Republic Era can be considered slightly different from the previous one as the differences can be shown in Table 1 (Kolluoğlu Kırlı 2007: 217). This new city now has a different face and a different population and it does not endeavor to settle with its glorious and conflicted past and to rediscover its long history (Smyrnelis 2009a: 22). To put it differently, whilst the urban landscape and population composition changed during this transformation, the urban identity and memory were also altered. Therefore, it would be worth considering this transformation by evaluating the street naming process and street names in both the Ottoman and Republic Eras as they reflect the social conditions and political mentality in which the city had been through and they can also be valid indicators of urban memory or tools to create a desired urban memory (or lieu de memoire) as mentioned above.

Table 1. Differences between Smyrna and Izmir

\begin{tabular}{|l|c|}
\hline Smyrna & Izmir \\
\hline Located in an Empire & Located in a nation state \\
\hline Multicultural and cosmopolitan population & Homogenized population \\
\hline Heterogeneous urban landscape & Homogeneous landscape \\
\hline $\begin{array}{l}\text { Under the influence of flexible and early } \\
\text { version of modernity }\end{array}$ & $\begin{array}{c}\text { Under the influence of well-structured and } \\
\text { rigid modernity }\end{array}$ \\
\hline
\end{tabular}

Source: Compiled from Kolluoğlu Kırlı 2007: 217.

\section{Streets, Street Naming and Street Names in Smyrna (before 1923)}

When Smyrna was becoming a major Levantine port city in the $16^{\text {th }}$ and $17^{\text {th }}$ centuries, even though the streets were packed with merchants from different nationalities and trade goods from different parts of the World, they were quite narrow and even the main street, the Frank street, which was paralleled to the coast, was dirty, ill paved, very narrow and too crowded. But in the $19^{\text {th }}$ century, the Frank Street and the Street of Roses (la rue des roses) became the most beautiful streets of the city (Smyrnelis 2009a: 11). It was no surprise that Frank Street had become well maintained as it was being organized in accordance with the complex trade system of the city with Europeans, it was the hearth of Frank Quarter and the rest of the city, especially the parts where European influences were being felt. However, the rest of the streets remained narrow and ill maintained and socioeconomic activities and relations were crammed into these narrow streets (Kolluoğlu Kırlı 2007: 226). Even though most of the streets were dirty, ragged and dangerous particularly at night and all types of crimes such as arson, homicide, extortion were not uncommon, the inhabitants of Smyrna met and interact with each other on these streets (Smyrnelis 2009b: 199-201). These interactions happened on the streets were one of the main factors contributing to 
the creation of cosmopolitan urban identity and its memories amongst the inhabitants. Even the narrow shape of the streets might have encouraged people to communicate with each other and this is what Halbwachs asserts about the formulation of collective identity as mentioned above. The collective identity of the city was being created naturally by the occurrences, happenings, interactions amongst all kinds of people which the city had during these centuries.

The city went through an earlier version of modernism towards the $20^{\text {th }}$ century which can be followed on the urban plans aimed to organize the city space in a more systematic manner than before considering the need to change the dominance of narrow, disorganized and rugged streets on the urban landscape. The first application of modern urban planning in the Ottoman Empire was introduced in Smyrna in 1840s when the Armenian quarter (Haynots) burned down (Bilsel 2009a: 146-147). While the locations of the modern port and train stations made the streets of the Frank Quarter around the Frank Street more vivid, the recently established Municipality of Smyrna (1874) opened up some news streets and tried to ameliorate some ragged streets especially in the southern districts where the Muslim and Jewish communities lived as the streets in these areas were more problematic and disorganized in comparison to the ones found in the Christian quarters. Governor Mithad Pasha (1880-1881) even tried to open up new boulevards connecting the rich and poor parts of the city but failed eventually (Bilsel 2009a: 154-159). What these instances point out is that the streets became a form of device to modernize the city for the interests of its economic life but, under these transformations the street names remained relatively the same ${ }^{2}$ and they could represent the socioeconomic and cultural features of their users and passersby as the streets were given names not in a systematic way in the Ottoman Empire but according to some symbols with which they were associated (Star, 2014). Therefore, it can be assumed that the street names in Smyrna were one of the indicators of its collective urban identity.

\footnotetext{
${ }^{2}$ The maps showing the growth of urban center of Smyrna from $17^{\text {th }}$ until $20^{\text {th }}$ centuries can be traced in Beyru (2011).
} 
Figure 1. Insurance Plan of Smyrna which was issued by Charles E. Goad in $1905^{3}$

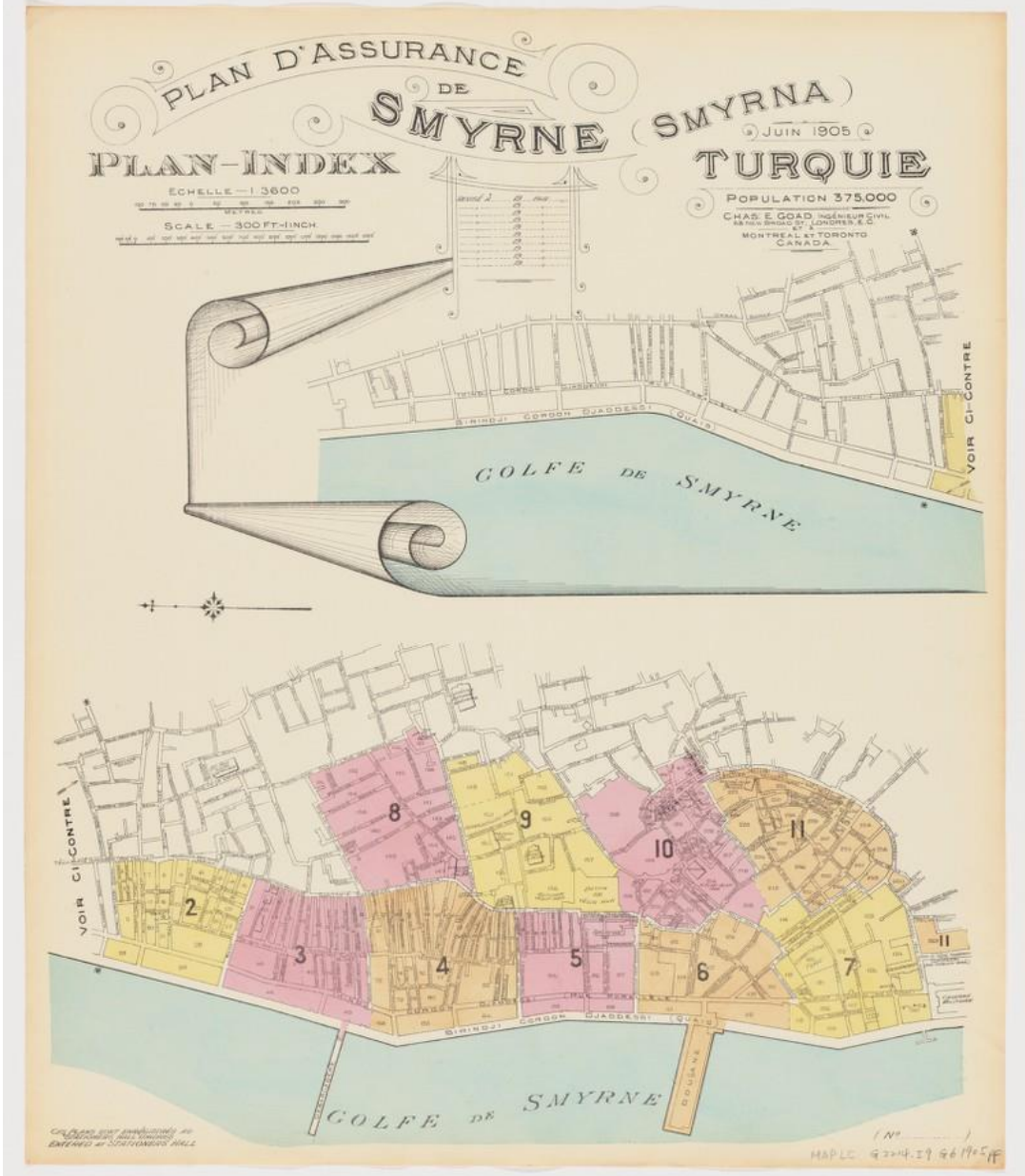

Source: Goad 1905.

In order to list the street names of Smyrna, Insurance Plan of Smyrna which was issued by Charles E. Goad in 1905 (Goad 1905) has been selected as this plan has the full list of street names for the each designed section (See Figure 1). The names found in the index of the plan and the other visible street names which are not included in the index since they are not located in the sections but can be seen on the map have been taken into consideration. Then, the names have been categorized into the seven basic classes depending on the meaning of the names. What is interesting is that even though the language of the map is French, different languages (French, Greek and Turkish) are used to name the streets on the map in a mixed way.

\footnotetext{
${ }^{3}$ For the high resolution images of each colored section and the table containing all of the street names, see the main source: Plan Index, Index, Plate number 2, 3, 4, 5, 6, 7, 8, 9, 10, and 11 in Goad, Charles E. Plan d'assurance de Smyrne (Smyrna): Turquie: plan, index. Londres: C. E. Goad, 1905. https://nrs.harvard.edu/urn-3:FHCL:3746611. [Accessed 6 September 2020.]
} 
Table 2. Categories of Street Names in the City Center of Smyrna in 1905

\begin{tabular}{|c|c|c|}
\hline Category & $\begin{array}{c}\text { Description } \\
\end{array}$ & Frequency \\
\hline $\begin{array}{l}\text { Commercial/Economic } \\
\text { Activities }\end{array}$ & $\begin{array}{l}\text { They generally refer to the names of trade } \\
\text { goods, commodities, professions and } \\
\text { passages (Turk. Ferhane (Frank House) - } \\
\text { Verhane. These passages emerged in the } \\
\text { 19th Century as trade centers alongside } \\
\text { the Frank Street. }\end{array}$ & 120 \\
\hline Landscape & $\begin{array}{l}\text { The names in this group refer to both the } \\
\text { natural and sociocultural features of the } \\
\text { relevant lands. }\end{array}$ & 38 \\
\hline Religion & $\begin{array}{l}\text { The names about Christianity and Islam } \\
\text { are covered in this section. They are about } \\
\text { the temples, saints and reverends of these } \\
\text { religions in general. }\end{array}$ & 14 \\
\hline Levantine Community & $\begin{array}{l}\text { The passages generally bear the names of } \\
\text { affluent Levantine families. Some family } \\
\text { names are also given to some streets. }\end{array}$ & 27 \\
\hline Greek Community & $\begin{array}{l}\text { Some passages and streets are associated } \\
\text { with Greek family names. Also some } \\
\text { streets are named after some saints revered } \\
\text { in the Greek Orthodox Church. }\end{array}$ & 30 \\
\hline Ottoman Bureaucrats & $\begin{array}{l}\text { Some streets are named after the Ottoman } \\
\text { bureaucrats and statesmen }\end{array}$ & 10 \\
\hline $\begin{array}{l}\text { Others and } \\
\text { Unidentifiable }\end{array}$ & $\begin{array}{l}\text { The features which do not fit in the other } \\
\text { categories or of unknown origin are listed } \\
\text { here }\end{array}$ & 44 \\
\hline
\end{tabular}

Note: Some street names are given place in more than one section as their meanings can be associated with multiple categories. See the Appendix 1 for the full list.

As seen in the Table 2, the street names of Smyrna represented the cosmopolitan nature of this Levantine and Ottoman port city. They were created by the relevant social, economic, cultural, communal activities with which the inhabitants were interacting in their daily lives and because of this fact, the street names of Smyrna could be considered as indicators of Halbwachs' notion of collective identity and Nora's concept of milieu de memoire. These names remained consistent during the centuries were the carriers of urban memory to the next generations.

\section{Street Naming in Izmir (after 1923)}

The Great Fire at Smyrna and the Population Exchange between Greece and Turkey had a profound impact on the topographic and demographic composition of the city: The city lost its Non-Muslim population and their built environment. Now the new city, Izmir, born out of the ashes of the old one became a political 
and nationalist case for the recently established modern Republic of Turkey as Izmir was the symbol of the National War of Independence (Alim Baran 2003: 75). Nationalism and modernism were the main themes of the political agenda of the newly founded Republic. The Reforms in Turkey aimed to transform the society to a modernist stage by political and administrative devices including urban planning (Bilsel 2009b: 250). ${ }^{4}$ Rebuilding Izmir was the product of this nationalist and modernist mentality as Izmir was a perfect experimental area since the city center had been destroyed to a great extent and the city was nationalized. In this regard, changing street names of Smyrna was one of the most effective implementations of the nationalist and modernist urban planning in Turkey back then.

The street names of this new city were changed by the decrees of Municipality of Izmir and the relevant meeting records about changing street names kept by the Municipality which were obtained from its archives ${ }^{5}$ shed light to underlying reasons for changes (or the total replacement) in street names. In this regard, on the $11^{\text {th }}$ of February in 1937 the Municipality accepted the proposal which was put forth by the commission established exclusively for the street names in order to change the street names. According to the proposal, streets whose lengths are longer than 20 meters must have a name but streets shorter than 20 meters must have a number instead and their old names shall be removed. Consequently, this decree removed all of the old street names some of which are shown in the Appendix 1 and replaced them with numbers or novel names. The reasons of the Municipality to change to street names can be found in the meetings records of this decree: It is expressed that "ancient and meaningless" names should be changed. The city is being rebuilt in a "scientific" way and the numeric system is considered more beneficial as streets are being organized vertically and horizontally. Even the Mayor himself refers to the American numeric street naming system as a useful system to categorize the streets. It is also stated that longer street names containing more words require bigger street name signs and therefore cost too much financial resources than the street name signs consisting of numbers only.

The main reason for the street naming process was to remove the former Ottoman and Levantine street names (Ürük 2008: 4). Thus, all of the street names now were of Turkish origin to make the city more national. This trend can be observed in the local newspapers of the city during this period as this changing process was described by local newspapers such as "changing unsuitable street names in order to give historical and beautiful names" (Anadolu 1937) and "Commission of Street Naming changed the names making nonsense" (Yeni Asir 1937). Street name changes in Izmir can also be evaluated within the context in which many topographic names were changed in Turkey due to the Turkification policy (Öktem 2008, Sahakyan 2010).

\footnotetext{
${ }^{4}$ In her study about the street names of Izmir, Asımgil also argues that this process has ideological and nationalist paradigms behind it (see Asımgil 2018).

${ }^{5}$ The meeting minutes of the Municipality used in these paper were obtained from Ahmet Piriştina Kent Arşivi ve Müzesi (2019).
} 
The large and long streets which needed to be named were given names after the high statesmen, military officials and republican values after the 1940s. The decree mentioned above immediately changed the names of First Cordon, Second Cordon and Guzelyali Tram Streets to Atatürk, Republic and Inönü Streets respectively on the $11^{\text {th }}$ of February in 1937. Four days later, this pattern was followed as the new squares of the city were given names by the Municipality after the names of the Treaties such as Lausanne and Montreux which are important for the establishment of the Republic and after the important dates like the $9^{\text {th }}$ of September which is the day Turkey retook Izmir in 1922. However, naming squares after the Treaties was a matter of debate because their names are not of Turkish origin. The solution could be found by the Municipality stating that these names were important reminders of the victories of the Republic and their Turkified equivalents were going to be used (Lozan and Montrö). The trend of naming streets after military officials (also martyrs) and statesmen was followed when the Municipality of Izmir named some boulevards such as Mithat Pasha, Veteran Osman Pasha, Martyr Sir Fethi, Martyr Nevres, Talat Pasha in 1951 (Ürük 2008: 3).

Considering the developments above, it can be stated that streets were named in the city center of Izmir by two main factors: Firstly; numbers and secondly; concepts, people and values which are important for the Republic. As discussed in the theoric approaches in the literature of street naming, numeric systems aim to make urban areas ordered, rational and value free while Republican names have a commemorative function. As Azarhayu puts it, commemorative street names indicate that a certain party wins the struggle in an urban setting and this is the Republican values in the case of Izmir. These designed names are an example of lieu de memoires as they are chosen by specific political agendas and only refer to a defined time period in history which is favored by political mentality while eliminating the other aspects of history and collective memory.

Despite the fact that the alphanumeric system, or just the numeric system in the case of street naming in İzmir, seems neutral and doesn't imply any commemorative meanings, the use of numbers as street names erased the actual street names from the urban memory of Izmir (Ürük 2008: 5). However, a few of them could survive these changes at least in daily uses; for example, people still call the $1382^{\text {th }}$ street as "Gul Sokak" (Originally; Rue des roses; street of roses).

Today, the numeric system still prevails the street naming system in Izmir (see Table 3). In this context, The City Council of Metropolitan Municipality of Izmir issued a decree on $13^{\text {th }}$ of January in 2014 aiming to guide all the district councils of Izmir about the changing of street names throughout all of the districts of the city. In this decree, it is expressed that the remaining street names, i.e., mostly numbers but also names about the Republican values, must not be changed in order to avoid any confusions in the urban address system by stating "changing names of places such as boulevards, avenues and streets disrupts the database of Geographic Address Information System and outdates the data processed in National Address Database" (İzmir Büyükşsehir Belediyesi 2014). Hence, the Municipality generally rejects the demands about changings of street names by referring this decree. After the tremendous changes of the street names before the 
1950s, the street names have remained the same because of the practical reasons (i.e., for the sake of navigation). This phenomenon can be observed by referring the Table 3; the numbers of streets given by the Municipality in 1940s still dominate the street names of the central part of Izmir as seen in the Table.

Table 3. Street Names in City Center of Izmir today

\begin{tabular}{|l|l|c|}
\hline Category & \multicolumn{1}{|c|}{ Description } & Frequency \\
\hline Numbers & $\begin{array}{l}\text { These numbers show the dominance of modernist Cartesian } \\
\text { logic over the street names }\end{array}$ & 149 \\
\hline Values & $\begin{array}{l}\text { The names in this group refer to values about the Republic/ } \\
\text { Political Regime/Ideology/Nationalism }\end{array}$ & 21 \\
\hline Others & $\begin{array}{l}\text { The names which do not fit in the other categories are listed } \\
\text { here }\end{array}$ & 12 \\
\hline
\end{tabular}

Note: The neighborhoods of Konak, Akdeniz, İsmet Kaptan, Kültür and Alsancak in contemporary Izmir have been chosen as the areas they roughly cover are approximately the areas shown in Charles E. Goad's map. See the Appendix 2 for the full list.

Because the street names were changed entirely, the Table 3 represents completely different names (with a different categorization) than the Table 2. Since the numbers are used for small streets, they have the highest frequency. However, Republican commemorative values are also dominant as the main streets and boulevards, which are obviously more prominent in the urban landscape than the smaller streets, are named after them. Both numeral Cartesian logic and commemorative function reflect the modernist and nationalist imagination which is in accordance with the values of the nation state. However, exceptions (others) can also be found; for example, there are also some street names named after renowned artists (see Appendix 2).

\section{Conclusion}

Streets are an inseparable part of people's daily lives and they are a very important source for the formation of collective identity. The elements of collective identity are shared amongst people on streets and their features make street names very important in terms of shaping collective urban memory as streets bearing their names have both material and social aspects of collective memory. Because of their functionality in this context, street names have become a political device for urban politics to spread desired values throughout the inhabitants of urban areas since the advent of Modernity. In this context, street names may lose their power to carry the elements of collective identity since designed street names only promote "a defined and limited" period of time and disregard the other aspects of cities. Therefore, desired and designed history suppresses actual elements of collective memory in urban spaces. Even though alphanumerical street naming system may ease the navigation and make the urban order in accordance with Cartesian logic, it may remove a certain part of urban identity by replacing names representing real aspects of city dwellers' lives with "value free" numbers and this implementation also relies on some values inherently such as the superiority of the 
logic of modernity. The experiences in street naming and street names in Smyrna/ Izmir provide some valuable findings in this regard.

Street names in Smyrna were representing the plurality that the city had in terms of its socioeconomic activities and demographic composition. The words/ terms associated with commercial activities, such as trade goods, titles of professions and passages were the most frequently used street names as the city owed its rise to its role in the international trade. The trade-associated names were followed by the signs of other pluralities; names from different communities, religious names from different religions. Landscape associated names were also in use as cultural and natural landscapes are inseparable parts of urban identity. As stated in the paper, urban infrastructure was being improved not only by Western merchants but also Ottoman bureaucrats who were trying to meet the former's demands. Therefore, some names associated with Ottoman bureaucrats were also not uncommon. In short, it can be stated that street names were demonstrating the elements of urban identity of back then-Smyrna.

However, when the street names in Izmir became a subject of politics of the modernist nation state, they lost their power of being a representative indictor of urban identity. The new street names in the city center are consisted of numbers or commemorative names in general. Their role is not to demonstrate the elements of urban identity, but to promote the Cartesian logic of modernism and the commemorative national values in Izmir today. This paradigm still prevails as it is shown in the relevant issues of the Municipality aiming to fix the contemporary street names in this manner.

It can be concluded that especially with the emergence of the commemorative street names imbued with the Republican ideology and numerical street names, street naming process in Izmir after the first quarter of the $20^{\text {th }}$ century as discussed throughout the paper presents a case which follows the patterns of transition from milieu de memoire to lieu de memoire alongside with the Cartesian logic. Therefore, it conforms to both urban politics of European nation states (i.e., the emergence of lieux de memoir) and the logic of American Cartesian ordered city, both of which have impacts on urban memory and identity. However, street naming is only one case in the forming of lieu de memoire and the modern urban spaces in the urban history of Izmir. This transition can also be traced by evaluating different aspects of urban identity and built environment in the city (or in another city in this regard). Depending on the relevant theoretical background, these studies might enrich our understanding about the relationships between place and people.

\section{References}

Ahmet Piriștina Kent Arşivi ve Müzesi (2019) Defter Grubu - Meclis Karar Tutanakları Meclis Karar Tutanaklart-17. (Ledger group - assembly decision minutes - assembly decision minutes-17) (1 February 1937 - 15 February 1937).

Alderman DH (2003) Street names and the scaling of memory: the politics of commemorating Martin Luther King, Jr within the African American community. Area 35(2): 163-173. 
Alim Baran T (2003) Bir kentin yeniden yapılanmast: İzmir, 1923-1938. (Reconstruction of a city: Izmir, 1923-1938). İstanbul: Arma.

Anadolu (1937) İmir Sokakları Ad mı Numara mı Tasslyacak? (Will the streets of Izmir be named with Names or Numbers?) The newspaper issue, dated on 5 February 1937. Ahmet Piriştina Kent Arşivi ve Müzesi. Retrieved from: https://www.apikam.org.tr/ [Accessed 10 September 2020.]

Asımgil B (2018) İzmir'de Kentsel Kimlik Bileșenlerinden Cadde Ve Sokaklarin Toponimisi Ve Milliyetçi, Etnik İzlerin Sosyal Yapi Oluşumuna Katkilari. (Street toponymy as components of urban identity in Izmir and contributions to social structure formation of ethnic culture). Trakya Üniversitesi Mühendislik Bilimleri Dergisi 19(1): 21-36.

Azaryahu M (1996) The power of commemorative street names. Environment and planning D: Society and Space 14(3): 311-330.

Azaryahu M (2011) The critical turn and beyond: the case of commemorative street naming. ACME: An International e-Journal for Critical Geographies 10(1): 28-33.

Azaryahu M, Kook R (2002) Mapping the nation: street names and Arab-Palestinian identity: three case studies. Nations and nationalism 8(2): 195-213.

Bilsel C (2009a) Modern Bir Akdeniz Metropolüne Doğru. (Towards a modern mediterranean metropolis). In MC Smyrnelis (ed.), I Ergüden (trans.), Izmir 18301930 Unutulmuş Bir Liman Kenti mi? Bir Osmanlı Limanindan Hatıralar, 143-160. İstanbul: İletișim.

Bilsel C (2009b) Bir Şehir Küllerinden Yeniden Doğuyor: Cumhuriyet Smyrna'sının Doğuşu. (A city is reborn from its ashes: the birth of republic Smyrna). In MC Smyrnelis (ed.), I Ergüden (trans.), Izmir 1830-1930 Unutulmuş Bir Liman Kenti mi? Bir Osmanlı Limanindan Hatıralar, 239-255). İstanbul: İletişim.

Beyru R (2011) 19. Yüzyllda İzmir Kenti. (The city of Izmir in the $19^{\text {th }}$ century). İstanbul: Literatür.

Boyer MC (1996) The city of collective memory: its historical imagery and architectural entertainments. The United States of America: Mit Press.

Goad CE (1905) Charles E. Plan d'assurance de Smyrne (Smyrna): Turquie: plan, index. (Charles E. insurance plan of Smyrna: Turkey, plan, index). Londres: Harvard Map Collection, Harvard University. Retrieved from: https://nrs.harvard.edu/urn-3:FHCL: 3746611. [Accessed 6 September 2020.]

Green A (2011) Can memory be collective. In DA Ritchie (ed.), The Oxford Handbook of Oral History, 96-111. New York: Oxford University Press.

Halbwachs M (1992) On collective memory. Chicago, USA: University of Chicago Press.

Harris R, Lewis R (2012) Numbers didn't count: the streets of colonial Bombay and Calcutta. Urban History 39(4): 639-658.

İzmir Büyükşehir Belediyesi (2014) Meclis Kararı. (Council decision). No:97509404.301. 05.22. Date: 13 January 2014. Retrieved from: https://www.izmir.bel.tr/tr/KararDeta yi/14720. [Accessed 10 September 2020.]

Kayın E (2010) Mekansal ve Sosyo-Ekonomik Ayrllısslar Geriliminde İzmir: KüreselYerel Fenomenler. (Izmir in the tension of spatial and socio-economic differences: global-local phenomena). In D Yıldırım, E Haspolat (eds.), Değişen İzmir'i Anlamak, 337-360. Ankara: Phoenix.

Kearns RA, Berg LD (2002) Proclaiming place: Towards a geography of place name pronunciation. Social \& Cultural Geography 3(3): 283-302.

Köksal Y (2018) Kent Mekanı ve Milliyetçilik: 19. Yüzyıl'da Osmanlı İmparatorluğu'nda Değişen Ağlar. (Urban space and nationalism: changing networks in the Ottoman Empire in the $19^{\text {th }}$ century). In PN Diamandouros, T Dragonas, Ç Keyder (eds.), E 
Kılıç (trans.), Mekan ve Millet. Yunanistan ve Türkiye'nin Coğrafyalarının Oluşumu, 53-71. İstanbul: Koç University Press.

Kolluoğlu Kırlı B (2007) Cityscapes and modernity: Smyrna morphing into Izmir. In A Frangoudaki, C Keyder (eds.), Ways to Modernity in Greece and Turkey, Encounters with Europe, 1950, 217-235. New York: I.B.Tauris \& Co Ltd.

Light L (2004) Street names in Bucharest, 1990-1997: exploring the modern historical geographies of post-socialist change. Journal of Historical Geography 30(1): 154172 ,

Mansel P (2011) Levant: splendour and catastrophe on the Mediterranean. USA: Yale University Press.

Mansel P (2014) Cities of the levant-the past for the future? Asian Affairs 45(2): 220-242.

Neethling B (2016) Street names: a changing urban landscape. In C Hough (ed.), The Oxford Handbook of Names and Naming, 144-157. New York: Oxford University Press.

Nora P (1996) Realms of memory rethinking the French past. New York: Columbia University Press.

Öktem K (2008) The nation's imprint: demographic engineering and the change of toponymes in Republican Turkey. European Journal of Turkish Studies. Social Sciences on Contemporary Turkey Thematic Issue $\mathrm{N}^{\circ} 7$, No. 7 | Demographic Engineering - part I, https://journals.openedition.org/ejts/2243 [Accessed 10 September 2020.]

Özveren E (2010) Dünden Bugüne İzmir İçin Artı ve Eksileriyle "Küresel Kent" leşme Süreci. (Process of being "global city" with pros and cons for Izmir from past to today). In D Yıldırım, E Haspolat (eds.), Değişen İzmir'i Anlamak, 107-134. Ankara: Phoenix.

Perlman M (1988) Imaginal memory and the place of Hiroshima. Albany: SUNY Press.

Rose-Redwood R, Kadonaga L (2016) "The Corner of Avenue A and Twenty-Third Street": Geographies of Street Numbering in the United States. The Professional Geographer 68(1): 39-52.

Rose-Redwood R, Alderman D, Azaryahu M (2017) The urban streetscape as political cosmos. In R Rose-Redwood, D Alderman, M Azaryahu (eds.), The Political Life of Urban Streetscapes, 23-46. New York: Routledge.

Sahakyan L (2010) Turkification of the toponyms in the Ottoman empire and the Republic of Turkey. Montreal: Arod Books.

Serçe E (2010) II. Meşrutiyet Döneminde Izmir. (Izmir during second constitutional era). In D Yıldırım, E Haspolat (eds.), Değişen İzmir'i Anlamak, 23-41. Ankara: Phoenix.

Smyrnelis M (2009a) Öndeyiş: Tarihini Arayan Şehir. (Preface: the city looking for its history). In MC Smyrnelis (ed.), I Ergüden (trans.), Izmir 1830-1930 Unutulmuş Bir Liman Kenti mi? Bir Osmanlı Limanından Hatıralar., 9-24. İstanbul: İletişim.

Smyrnelis M (2009b) Dekorun Arka Yüzü. (The back of the decor). In MC Smyrnelis (ed.), I Ergüden (trans.), Izmir 1830-1930 Unutulmuş Bir Liman Kenti mi? Bir Osmanl Limanindan Hatıralar, 197-207. İstanbul: İletişim.

Star (2014) Sokak isimleri değişirken hafiza da siliniyor. (Memory is erased as street names change). star.com.tr, 15 November 2014. Retrieved from: https://www.star.com.tr/ pazar/sokak-isimleri-degisirken-hafiza-da-siliniyor-haber-966812/. [Accessed 10 September 2020.]

Taşci B, Özden B, Davras F, Akkurt HB (2015) Rediscovering the $19^{\text {th }}$ century of a port town in Levant: Smyrna/Izmir. Athens Journal of Mediterranean Studies 1(1): 61-80.

Ürük Y (2008) İzmir'i İzmir Yapan Adlar. (The names that make the city of Izmir). Izmir: İzmir Metropoliten Municipality. 
Vuolteenaho J (2012) Numbering the streetscape: mapping the spatial history of numerical street names in Europe. Urban History 39(4): 659-679.

Yeni Asır (1937) Şehir meclisi toplandr. (The city council convened). The newspaper issue, dated on 12 February 1937. Ahmet Piriştina Kent Arşivi ve Müzesi. Retrieved from: https://www.apikam.org.tr/. [Accessed 10 September 2020.]

Yeoh BS (1996) Street-naming and nation-building: toponymic inscriptions of nationhood in Singapore. Area 28(3): 298-307. 
Appendix 1. Street Names in the City Center of Smyrna in 1905

Street names associated with:

\begin{tabular}{|c|c|}
\hline $\begin{array}{l}\text { Commerce/Economic } \\
\text { Activities }\end{array}$ & $\begin{array}{l}\text { Customs Access, Algeria (South Coast)), Anastasse Agha } \\
\text { Passage, Arabic Market, Arabic Passage, Solicitor (Profession), } \\
\text { Bakur Gallery, Honeymakers, Fish Market, Barbaressi Inn, } \\
\text { Glassmakers, Gun Powder Market, Flourishing (?), Flea } \\
\text { Market, Boscovitch Passage, Devil's Market, Confectioners, } \\
\text { Javalinmakers, Cousinery, Critikos Inn, Iron, Blacksmith, } \\
\text { Dervişoğlu Inn, Algeria Inn, Old Fish Market, Old Customs, } \\
\text { Old Chokha Gallery, Fassoulia Square, Fassoulia, Frank, Gioya } \\
\text { Inn, Grand Taverns, Ekizler Passage, Pancake Makers' Market, } \\
\text { Halim Aga Market, Wicker Makers, Homer Passage, Homsy } \\
\text { Passage, Honischer Passage, Hardware Stores, English Pier, } \\
\text { Weighers, Butchers, Kemeralti (Colonnade), Lumbermen, } \\
\text { Lumbermen's Market, Chestnut Market, Linen Market, } \\
\text { Beltmakers' Market, Goats, Jewelers, Kupecioglu Passage, } \\
\text { Levy Passage, Lemon Sellers, Lombardo Passage, Mine, } \\
\text { Matthew Passage, Megistis Lavras Passage, Meyvedar } \\
\text { (Fruitful) Custom, Clamp (?),Minghetti Passage, Moraitine } \\
\text { Passage, Natali Pier, Negrepont Passage, Wood Market, } \\
\text { Osmaniye (Ottoman), Apricot and Road Bedesten, Saddle } \\
\text { Makers' Market, Peshtemal Makers, Peshtemalgioglu Passage, } \\
\text { Cheesemongers' Market, Psaro Hano (Greek: Fish Market), } \\
\text { Quais (Docks), English Quay, Rossi Passage, Rouk Passage, } \\
\text { Soap Factory, Sakizli Inn, Saman (Hay) Pier, Chest Makers' } \\
\text { Market, Sayian passage, Sofianopoulo Passage, Spanoudhi } \\
\text { Passage, Spartali Passage, Sponti Passage, Stepenapoulos } \\
\text { Passage, Synaitiko Passage, Circlet, Circlet Makers, Circlet } \\
\text { Makers' Market, Poulterer's Market, Pocketknife Market, } \\
\text { Bowl, Bag Makers' Market, Tchanguirli (?) Market, Drawer } \\
\text { Makers' Market, Chocolate (?), Nail Makers' Market, Clasp } \\
\text { Makers' Market, Tenekides Passage, Terdjimanoglou Passage, } \\
\text { Teskere (Stretcher?), Salt Storage, Pressers, Vlissides Passage, } \\
\text { Whitetall Passage } \\
\text { Oil maker, Nuts Market, New Flea Market, Road Market, } \\
\text { Youssouf Passage, Sir Youssouf Passage. } \\
\text { Vegetables, Chandler, Tea, Grand Dyehouse, Powder Maker, } \\
\text { Chicken, Hen, Big Swine, Rabbit, Locksmith. }\end{array}$ \\
\hline Landscape & $\begin{array}{l}\text { Goldenriver, Head Seat Square (?), Garden, Flourishing (?) } \\
\text { (Commerce-Landscape), First Cordon, Pine Garden (?), } \\
\text { Apricot, Second Cordon, Back of Castle, Partridge, Kemeralti } \\
\text { (Colonnade), Kemeralti (Colonnade) Mosque, Hisar (Fortress) } \\
\text { Mosque Square, Elaeagnus, Köprülü (Bridged) Street (?), Cut, } \\
\text { Tulip, Long, Parallel, Borealis, Quais (Docks), English Quay, } \\
\text { Hidden, Yellow, Onion Castle, Soumi Graveyard, Suzekli } \\
\text { (Continious) (?), Below the Fountain, Muddy, Clove, Lilly, } \\
\text { Spring, Stone Bridge, Cherry, Roses (Rue des Roses), Cypress, } \\
\text { Well, Forest. }\end{array}$ \\
\hline Religion & $\begin{array}{l}\text { Saint George, Catholic Church Passage, Haci Huseyin Mosque, } \\
\text { Hisar (Fortress) Mosque Square, Imam Han Square, Grand and } \\
\text { Small Imam Han, Monk, Kemeralti (Colonnade) Mosque, } \\
\text { Patriarch of Jerusalem Passage, Saint George, Saint Mary, Saint } \\
\text { Photeini, Vakif Hodja, Cathedral. }\end{array}$ \\
\hline
\end{tabular}




\begin{tabular}{|c|c|}
\hline Levantine Community & $\begin{array}{l}\text { Aliotti, Baltaci, Catholic Church Passage, Fassoulia Square, } \\
\text { Fassoulia, Frank, Homer Passage, Homsy Passage, Honischer } \\
\text { Passage, English Pier, Levy Passage, Lombardo Passage, } \\
\text { Maltese, Matthew Passage, Minghetti Passage, Moraitine } \\
\text { Passage, Natali Pier, Negrepont Passage, Impasse of } \\
\text { Providence, English Quay, Rafnewski, Rossi Passage, Rouk } \\
\text { Passage, Whitetall Passage, Charnaud, Natali, Bella Vista. }\end{array}$ \\
\hline Greek Community & $\begin{array}{l}\text { Antiprikides, Saint George, Athanissiades, Carfisdhika } \\
\text { (probably Greek origin?), Greek Embassy, Anastasse Agha } \\
\text { Passage, Critikos, Critikos Inn, Fassoulia Square, Fassoulia, } \\
\text { Kenourio, Megistis Lavras Passage, Phaeton, Psaro Hano, } \\
\text { Greek Hospital, Saint George, Saint Photeini, Yellow George, } \\
\text { Sofianopoulo Passage, Spanoudhi Passage, Spartali Passage, } \\
\text { Sponti Passage, Stepenapoulos Passage, Synaitiko Passage, } \\
\text { Tsigharohartadhika, Vlissides Passage, Yaliadhika, George, } \\
\text { Pantelis, Triantafilides. }\end{array}$ \\
\hline Ottoman Bureaucrats & $\begin{array}{l}\text { Ali Pasha (Kemeralti), Ali Pasha (or Old Courthouse), } \\
\text { Gentlemen (Ottoman Bureaucrat-Social Acitivity?), Şahinzade } \\
\text { Square and Street, Sir Şeker, Sir Hamid, Kaymak Pasha, } \\
\text { Kasapoglu (?), Köprülü Han Manor, Köprülü (Bridged) Street } \\
\text { Mahmudiye (?). }\end{array}$ \\
\hline Others and Unidentifiable & $\begin{array}{l}\text { Akkar (Proper noun?), Alhambra (Theater), Attar (Unknown } \\
\text { Origin), Araicik (Unknown Origin), Across the Municipality } \\
\text { (Government Building), Gentlemen (Ottoman Bureaucrat- } \\
\text { Social Acitivity?), Municipality First (Government Building), } \\
\text { First Ladies House (Social Activitiy), Dilber (Ottoman name), } \\
\text { Djidjifia (?), Doudou (A female name?), Doullar (?), Ekizler (A } \\
\text { family name?), Old Courthouse (Government Building), Gales } \\
\text { (?), Haci Stamo (?), Haik (?), Halici (?), Hamam (Turkish } \\
\text { Public Bath) (Social Activity), Hopitaux (Hospitals) } \\
\text { (Medicine), Ibirsim House (?), Idil Roubah (?), Second Ladies } \\
\text { House (Social Activity), Khorassannian (A family name?), } \\
\text { Girls (Social Activity), Manor (Government Building), } \\
\text { Mavunaci (?),Russian (?), Nihadiye (?), Osmanll (Ottoman) } \\
\text { Post Office, Asvan (?),Reilir (?), Safakhat (Ottoman?), Sahur } \\
\text { (?),Soultanie (Ottoman), Tchadjilar (?Probably associated with } \\
\text { Turkish), Teşrifiye (Ottoman name associated with honour and } \\
\text { dignitiy), Roulane (?). Past, Courthouse (Government } \\
\text { Building), Instrumentalist Sister (?), Noise, Kamburoglu (A } \\
\text { Turkish surname), Reçide (?), Souzan (a Turkish female name). }\end{array}$ \\
\hline
\end{tabular}




\section{Appendix 2. Street Names in the City Center of Contemporary Izmir}

Street names associated with:

\begin{tabular}{|c|c|}
\hline Numbers & 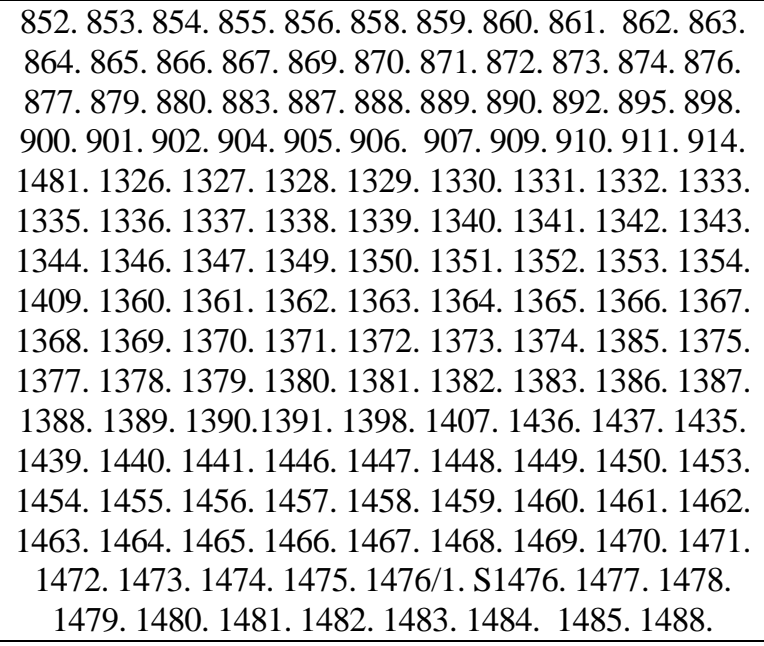 \\
\hline $\begin{array}{l}\text { Values about the Republic/Political } \\
\text { Regime/Ideology/Nationalism }\end{array}$ & $\begin{array}{c}\text { Republic, Martyrs, Atatürk Square, Architect } \\
\text { Kemalettin, Sir Martyr Fethi, Governor Kazım Dirlik, } \\
\text { Republic Square, Veteran Osman Pasha, Veteran, The } \\
9^{\text {th }} \text { of September Square, Fevzi Pasha, Freedom, } \\
\text { Atatürk, Martyrs of Cyprus, Mahmut Esat Bozkurt, } \\
\text { Vasıf Çınar, Plevne, Lausanne Square, Talat Pasha, Ali } \\
\text { Çetinkaya, Republic } \\
\end{array}$ \\
\hline Others & $\begin{array}{l}\text { Love Way, Silk Market, Mucibur Rahman, } \\
\text { Mediterranean, Halit Ziya, Necati Bey, Poet Eşref, } \\
\text { Kızılay (Red Crescent), Bedia Muvahhit, Italy, Professor } \\
\text { Doctor Nusret H. Fişek, Sait Altınordu }\end{array}$ \\
\hline
\end{tabular}


